\title{
Optimizing State-Owned Enterprises Land Assets using HBU and Value-Based Decision
}

\author{
Ifan Susanto $^{1}$ and Christiono Utomo ${ }^{1}$
}

\begin{abstract}
Competitive business climate, lack of capital and urban land function changes have an impact on land assets that are not optimally used. State-owned land with an area of 32,495 m2 with a market value of 227,773,000,000 rupiah contained a cultural heritage building. The land is located in the east Kalimantan corridor, trade zone and service, which is the waterfront city development area of the city of Surabaya. This study aims to optimize assets and find the best development alternatives in asset utilization to become a profit center for the company. Based on surveys and interviews, found that the possible development alternatives to be carried out were Mixed Use Commercial (a1), Diesel Engine Industry (a2) and Maximize Workshop capacity (a3). Highest and Best Use (HBU) was found to be one of the techniques of decision making in the development of land and property. $\mathrm{HBU}$ criteria are used to build a valuebased decision hierarchy. Analytical Hierarchy Process (AHP) is applied to develop decision making processes based on preferences and the best choices. The best alternative is obtained from the Satisficing Option calculation. This result is obtained by comparing functions to costs. The function is obtained from the $\mathrm{HBU}$ criteria and costs come from the estimated initial costs and life cycle costs (Life Cycle Cost). Based on financial analysis calculation obtained that mixed-use commercial development has the highest and best use Net Present Value (NPV) IDR 2,470,771,622,513 with an investment cost of IDR $1,367,230,380,324$. Internal Rate of Return (IRR) is $20.66 \%$ with a payback period of 6.70 years. Based on AHP analysis with HBU-Value Based Decision criteria and Satisficing Option calculations it was found that the mixed-use commercial property development is a development alternative chosen by stakeholders to optimize BUMN assets.
\end{abstract}

Keywords-Highest and Best Use, Life Cycle Cost, Value Based, Land Development, Analytical Hierarchy Process.

\section{INTRODUCTION}

Many State-Owned Enterprises (SOE) assets have not been used productively and not optimally utilized. While many land assets are located in strategic commercial areas. Competitive business climate, lack of capital and urban land function changes have an impact on land assets that are not optimally used. Figure 1 shows object location of assets at KH Mas Mansyur Street Surabaya. SOE assets covering 32,495 sqm with IDR 227,773,000,000 market value containing cultural heritage building[1].

\footnotetext{
${ }^{1}$ Ifan Susanto and Christiono Utomo are with Institut Teknologi Sepuluh Nopember, Surabaya, Indonesia, 60111, Indonesia. E-mail: Ifan.susanto1@gmail.com; christiono@ce.its.ac.id.
}

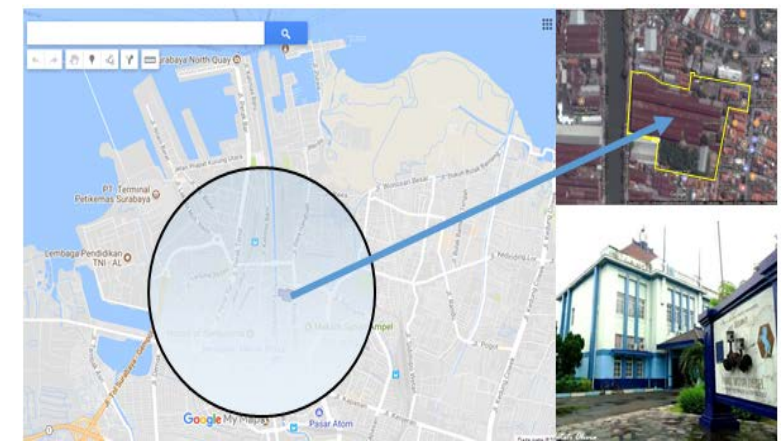

Figure 1. SOEs Assets at KH Mas Mansyur Street Surabaya.

Assets currently used for steel construction manufacturing, but still far from capacity and utility accordance with its designation. Management need to optimize their utilization and effort to improve company performance and value.

Utilization of SOEs fixed assets into commercial property in Srabaya has been widely carried out. De Papilio Tamansari apartment and condotel at 176-178 Ahmad Yani Street Surabaya is standing on the land of the former Wijaya Karya office before. ITC Mega Grosir located at 20-30 Gembong Street Surabaya is standing on land owned by the National Gas Company (PGN). Pesonna Hotel at 1 Benteng Street Surabaya stands on Pegadaian land. Pelindo Place at Perak Barat Street which in the construction process is a 23storey Office Tower owned by Pelindo. With existing examples, the utilization of state-owned fixed assets into commercial property can be taken into consideration.

One approach to find out the function of land is Highest and Best Use (HBU). HBU analysis was used as one of the important techniques in finding the best alternative to be used in developing vacant land or existing assets to increase property. Previous research shows that HBU is used to support decision systems[2]. The authority of the director as decision maker is very limited, it requires collaboration with one level officials under the director, commissioner and city government regarding the status of cultural heritage buildings as well as a correlation with the vision and mission of SOEs company.

This study aims to determine the use of $\mathrm{HBU}$ in supporting the decision-making process to choose the best alternative to be used in optimizing the assets of SOEs in North Surabaya. The concept of value-based decisions as 
well as collaborative decision making is applied and integrated with HBU to develop decision support systems in obtaining appropriate decisions. This is an innovative concept in property development or real estate, where decisions do not only consider financial or design criteria as found in almost cases of property development. However, stakeholder preferences may have some views regarding the choice of development considering the core business, vision and mission of the mission of SOEs.

\section{LITERATURE REVIEW}

Optimizing the utilization of asset is terms of service benefit and financial returns[3]. Land and buildings are considered as fixed assets while Property is a legal concept that concerns the interests, rights and benefits associated with ownership. Definition of real property begins with the surface of a parcel of land and moves on to the owner's rights to the air above the surface and the soil and minerals beneath the surface, as well as anything permanently attached to this land, either by nature or by human hands. real property can be divided into four major classifications: 1. Residential; 2. Commercial; 3. Industrial; 4. Special purpose[4].

Siregar [5] states that optimizing asset management must maximize asset availability, maximize asset utilization, and minimize cost of ownership. Utilization assets which also said asset management is wealth management that includes the process of planning asset needs, obtaining, inventorying, legal auditing, valuing, operating, maintaining, updating or eliminating to transfer assets effectively and efficiently[6]. Fixed assets utilization can done by SOEs alone or cooperation with other parties. It's can be done by Build Operate Transfer (BOT), Build Transfer Operate (BTO), Joint Operation (KSO) or Business Cooperation (KSU)[7].

One concept approach to develop assets that not optimally, identify the highest and best use of vacant land that has been developed is HBU analysis. The reasonably probable and legal use of vacant land or an improved property that is physically possible, appropriately supported, financially feasible, and that results in the highest value. Highest and best use of a property is an economic concept that measures the interaction of four criteria: legal permissibility, physical possibility, financial feasibility, and maximum profitability[8]. There are 2 (two) types of HBU analysis, HBU from vacant land / land that is considered empty and HBU from properties that have been built[9].

While HBU is a concept of valuation that can be applied to land or buildings that are usually interpreted with land use[10]. Value-based decisions are structural and analytical processes that aim to achieve value by identifying all the necessary functions at the lowest cost, while maintaining the required level of quality and performance[11]. This method consists of value-based processes and multi-criteria decision processes based on values in functions divided by costs.

\section{METHOD}

This research builds on three body of knowledge that are property, HBU and value-based decision. The method is adopted from[12]. Three body of knowledge will analyzing and making decisions from optimization of the object. Purposive sampling technique used for selected respondents. Purposive sampling is a non-probability sampling method and it occurs when "elements selected for the sample are chosen by the judgment of the researcher. Purposive sampling is known as judgmental, selective, or subjective sampling[13]. Respondents were chosen with consideration that directly involved or have ability and understanding regarding the use of the object.

\section{A. Function Analysis of the Highest and the Best Use}

Function Analysis is a systematic process for identifying functions and costs involved, and assessing the needs of these functions based on the criteria set for the product or service. While the Function Analysis System Technique (FAST) is a systematic diagramming technique for managing functions and describing the inter relationships between these functions[14]. Based on the technical function analysis (FAST) process, the main function of HBU has 4 (four) secondary functions or derivatives of the main functions, namely legal, physical, financial, and maximum productivity.

\section{B. Life Cycle Cost}

Life Cycle Costs (LCC) is economic value technique by calculating all relevant costs during the investment period with consider on time value of money. Refers to the development process of property buildings. LCC process follows the development stage in the form of initial, design, formal negotiation, construction, and property management[15]. LCC as development costs consist of capital costs, energy costs, operating and maintenance costs and replacement costs. Calculating LCC equation can be used is: present worth $(\mathrm{Pw})$ of LCC $=$ Investment cost $+\mathrm{Pw}$ operation cost $+\mathrm{Pw}$ maintenance cost $+\mathrm{Pw}$ energy cost + $\mathrm{Pw}$ replacement cost $+\mathrm{Pw}$ salvage value. It can be calculated using theory of time value of money[12].

\section{HBU and Value-based Decision}

Value-based process analysis carried out based on HBU criteria and development costs for each alternative. Alternative selection process is done by multi-criteria decisions. This stage consists of four steps, namely: 1 . Develop a decision hierarchy; 2. Create a paired placement matrix; 3. Assessment Synthesis; 4. A satisfying choice for the best alternative based on value criteria. The first three steps follow the evaluation process in AHP[16]. The final step is an evaluation model based on Value-Based Decisions.

In multi criteria decision making (MCDM), satisfying choices are used by linking functions and costs to obtain values from alternative solutions[12]. Technical solution 
options are categorized into 'Costs' identified based on development costs and 'Functions' identified based on HBU criteria. The value of each alternative is calculated based on the value equation that is function per cost. The best alternative is the highest value alternative.

\section{RESUlTS AND DisCUSSION}

Previous Study says that optimizing the land assets which located near the river has concluded that mixed use commercial building are the best alternative to developing assets[2]. Object located at East Kalimas Corridor, commercial zone and part of heritage Surabaya's water front city development[17]. The assets currently used for steel structure fabrication workshop, but far from its capacity and designation. Had been a deutz brand diesel factory in the new order. Based on literature and preliminary interviews with stakeholders, the possible alternative development options are: 1. Mixed-use commercial building; 2. Diesel engine manufacture; 3. Maximize workshops capacity.

\section{A. Physical Analysis}

Mix-use commercial development option consider based on object location at Tanjung Perak V Development Unit. The main functions of the environmental center of this unit include ports, national defense and security areas, strategic industrial zones, trade and services, and protection of buildings and cultural heritage environments[18]. Development follows the rules of the Surabaya spatial plan and city building code[19]. Figure 2. shows plans for developing a mix of retail, apartment and hotel functions. Life style mall is planned with 4 (four) floors high, 3 (Three) towers with 22 floors apartment and hotel.

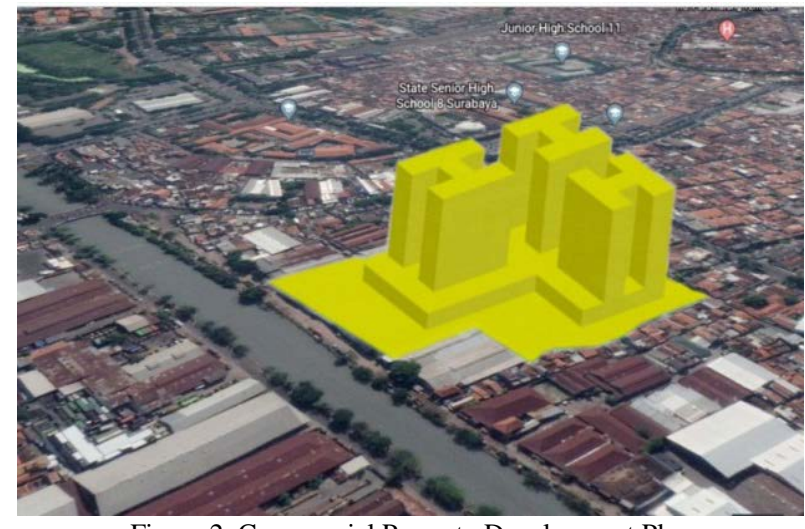

Figure 2. Commercial Property Development Plan

Indonesia is the largest machine market in Southeast Asia. Diesel market projected rise up to 6 times higher than the average 2 percent of global demand. Second option is redevelop diesel engine factory for marine engine, heavy equipment, agriculture and power plants. Development will collaborate with third parties Join Operation with the stages in Table 1.
TABLE 1.

STEP FOR DIESEL ENGINE PRODUCTION

\begin{tabular}{|c|c|c|}
\hline Description & Years & Remarks \\
\hline $\begin{array}{l}\text { Engine Sales } \\
\text { (Completely } \\
\text { Assembled) }\end{array}$ & 2 & Completely assembled engines from Doosan \\
\hline $\begin{array}{l}\text { SKD } \\
\text { (Semi- } \\
\text { Knock } \\
\text { Down) }\end{array}$ & 2 & $\begin{array}{l}\text { Base engine from Doosan, Exterior parts can } \\
\text { be sourced by Indonesia partner, Assembly } \\
\text { facility, Engine test facility }\end{array}$ \\
\hline $\begin{array}{l}\text { CKD } \\
\text { (Complete } \\
\text { Knock } \\
\text { Down) }\end{array}$ & 3 & $\begin{array}{l}\text { Major and in-house machined components } \\
\text { from Doosan, Remaining parts can be } \\
\text { sourced by Indonesia partner, Organized } \\
\text { assembly line \& facility, Engine test facility }\end{array}$ \\
\hline $\begin{array}{l}100 \% \\
\text { Localization }\end{array}$ & 3 & $\begin{array}{l}\text { Established machining line for , } 100 \% \\
\text { localized or sourced parts by Indonesia } \\
\text { partner, Fully organized machining, } \\
\text { assembly line \& facility, Engine test facility }\end{array}$ \\
\hline Design & 5 & $\begin{array}{l}\text { Start design next generation engines under } \\
\text { cooperation with Doosan }\end{array}$ \\
\hline
\end{tabular}

Another development option is company does not make changes to the current function and no large investment plan for the object. Development only done to expand the loading area complete with material handling supporting the process of loading and unloading material fabrication. Fabrication capacity increase planned from 1200 to 4200 tons per year.

\section{B. Financial Analysis}

Financial analysis is carried out to measure feasibility of development alternative investment planned. The analysis is carried out to calculate development investment costs, income from sales of goods or services, operational costs, maintenance costs, cash flow projections and investment feasibility analysis.

To analyze the financial feasibility of each alternative, several assumptions are needed, including the percentage of $30 \%$ own capital ownership and bank loan capital of $70 \%$. The bank loan interest remains at $10.50 \%$ with a repayment period of 10 years and a MARR of 18\%. Investment feasibility of each alternative is shown in Table 2.

TABLE 2.

FINANCIAL FEASIBILITY ANALYSIS

\begin{tabular}{lllll}
\hline \hline Analysis & Unit & Commercial (a1) & Diesel (a2) & Workshop (a3) \\
\hline Inv. Cost & $\begin{array}{l}\text { IDR } \\
\text { (million) }\end{array}$ & $1,367,230$ & $2,592,100$ & 9,297 \\
NPV & IDR & $2,430,709$ & $(426,513)$ & 33,107 \\
(million) & & 5.00 & 36.70 \\
IRR & $\%$ & 20.66 & 0.90 & 1.17 \\
BCR & & 1.65 & 24.01 & 3.99 \\
PP & Year & 6.30 & & \\
\hline \hline
\end{tabular}

\section{Construction Decision Hierrchy}

4 (four) level decision hierarchy composition consists objectives, criteria, sub criteria and alternatives. A decision hierarchy is a representation of a problem that is structured into a different component. The hierarchy arrangement is shown in Figure 3. 
The $1^{\text {st }}$ International Conference on Business and Management of Technology (IConBMT)

August 3rd 2019, Institut Teknologi Sepuluh Nopember, Surabaya, Indonesia

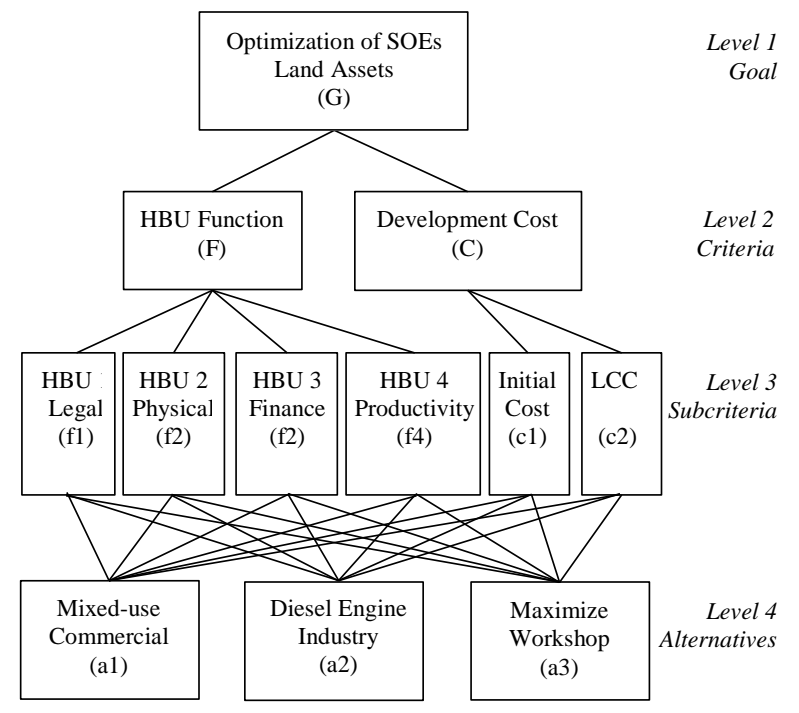

Figure 3. Decision Hierarchy

The goals to be achieved from this MCDM process are Optimization of the assets. Next two criteria, HBU Function and Development Cost are divided into sub-criteria. HBU Function sub-criteria is legal, physical, financial and productivity. Where the sub-criteria of Development Cost are Initial Cost and Life Cycle Cost (LCC)[12]. Each sequence of HBU sub-criteria is given the letters $\mathrm{f} 1, \mathrm{f} 2, \mathrm{f} 3$ and $\mathrm{f} 4$. While the two Initial Cost and LCC sub-criteria are given letters $\mathrm{c} 1$ and $\mathrm{c} 2$. The bottom is alternatives that come from stakeholder preferences, namely Mixed Use Commercial (a1), Diesel Engine Industry (a2) and Maximize Workshop (a3).

\section{Making Judgment}

Based on the decision hierarchy, pairwise comparisons of each sub-criteria are carried out using the rating scale of the AHP which consists of grades 1 to 9 and the opposite of those values which are $1 / 9$ to $1 / 2$. The results of subcriteria assessment through pairwise comparisons made by stakeholders can be seen in Table 3.

TABLE 3.

PAIRWISE COMPARISON CRITERIA

\begin{tabular}{lcccccc}
\hline \hline & $\begin{array}{c}\text { HBU1 } \\
\text { Legal } \\
\text { (f1) }\end{array}$ & $\begin{array}{c}\text { HBU2 } \\
\text { Physical } \\
\text { (f2) }\end{array}$ & $\begin{array}{c}\text { HBU3 } \\
\text { Finance } \\
\text { (f3) }\end{array}$ & $\begin{array}{c}\text { HBU4 } \\
\text { Productivity } \\
\text { (f4) }\end{array}$ & $\begin{array}{c}\text { Initial } \\
\text { Cost } \\
\text { (c1) }\end{array}$ & $\begin{array}{c}\text { LCC } \\
\text { (c2) }\end{array}$ \\
\hline (f1) & 1.000 & 0.517 & 0.339 & 0.339 & 1.108 & 0.351 \\
(f2) & 1.933 & 1.000 & 0.931 & 1.093 & 2.667 & 0.453 \\
(f3) & 2.954 & 1.074 & 1.000 & 1.552 & 1.635 & 0.548 \\
(f4) & 2.954 & 0.915 & 0.644 & 1.000 & 1.380 & 0.301 \\
(c1) & 0.903 & 0.375 & 0.612 & 0.725 & 1.000 & 0.211 \\
(c2) & 2.853 & 2.208 & 1.825 & 3.323 & 4.743 & 1.000 \\
$\lambda \max =6.1507$ & $\mathrm{CI}=0.0296$ & $\mathrm{CR}=0.0239$ & \\
\hline \hline
\end{tabular}

Furthermore, from the assessment process through pairwise comparisons, the criteria weights are shown in
Figure 4. From the picture it can be seen that the Life Cycle Cost (LCC) is the most important criteria, then followed by Financial criteria. This is easy to understand because in optimizing SOEs assets Life Cycle Costs are very important things to consider.

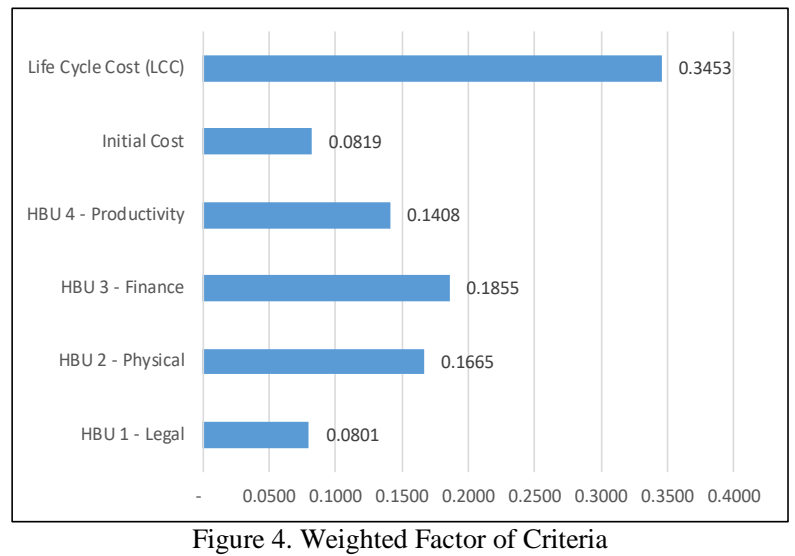

\section{Judgment Synthesis}

The next step, after the previous two steps is to do the synthesis synthesis. The results of this process are ranking from alternatives for each subcriteria. The full results can be seen in Figure 5.

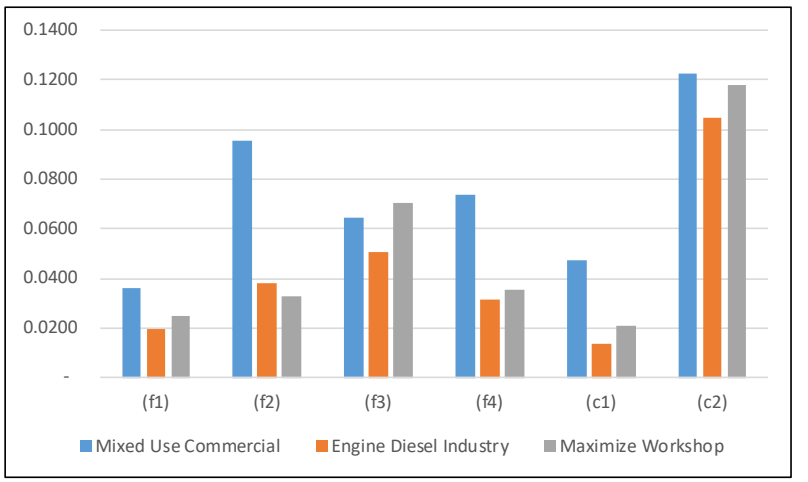

Figure 5. The Best Alternatives for Each Evaluation Criteria

\section{E. Satisfacing Option}

The fourth step is a satisfying choice for the best alternative. Stirling [20] stated that 'A natural procedure of satisficing options is to separate the attributes into two categories, one to involve the attribute that represents functions of an option and the other is to involve attributes that represents losses'. Where these results are obtained from comparisons between functions and costs that represent the value of technical solutions, they must be represented on the same scale. This can be done by making the ability to choose (Ps) and the ability to reject (Pr) function and normalization of the problem so that the decision maker has a unit of utility functions and unit utility costs to divide between options. Table 4 shows the utility of cost and function for each option of land use solution. 
The $1^{\text {st }}$ International Conference on Business and Management of Technology (IConBMT) August 3rd 2019, Institut Teknologi Sepuluh Nopember, Surabaya, Indonesia

TABLE 4.

SATISFICING OPTION FOR FUNCTION AND COST

\begin{tabular}{|c|c|c|c|c|c|c|c|c|c|c|c|c|}
\hline & \multicolumn{6}{|c|}{ Function } & \multicolumn{5}{|c|}{ Cost } & \multirow{2}{*}{$\begin{array}{c}\text { Value } \\
\text { F/C }\end{array}$} \\
\hline & (f1) & (f2) & (f3) & (f4) & $\sum$ & (Ps) & (c1) & (c2) & $\sum$ & Loss & $(\mathrm{Pr})$ & \\
\hline (a1) & 0.036 & 0.096 & 0.064 & 0.074 & 0.270 & 0.471 & 0.047 & 0.122 & 0.169 & 0.118 & 0.272 & 1.736 \\
\hline (a2) & 0.019 & 0.038 & 0.050 & 0.032 & 0.139 & 0.243 & 0.014 & 0.105 & 0.118 & 0.169 & 0.388 & 0.626 \\
\hline (a3) & 0.025 & 0.033 & 0.071 & 0.036 & 0.164 & 0.286 & 0.021 & 0.118 & 0.139 & 0.148 & 0.340 & 0.840 \\
\hline & & & & $\sum$ & 0.573 & & & & $\Sigma$ & 0.436 & & \\
\hline
\end{tabular}

The final step is to determine which alternative to choose and alternative to reject is through the calculation of the Satisficing Option. Where if the calculation of function (F) is divided by cost $(\mathrm{C})>1$ then the alternative is accepted, but if the result of the calculation of function $(\mathrm{F})$ is divided by cost $(\mathrm{C})<1$ then the alternative is rejected. Figure 6 provides a cross plot of function and cost, alternative 1 (Mixed Use Commercial) is accepted with value for the function of cost $>1$, while the other 2 alternatives (a2 and a3) are rejected because the value of the function to cost < 1.

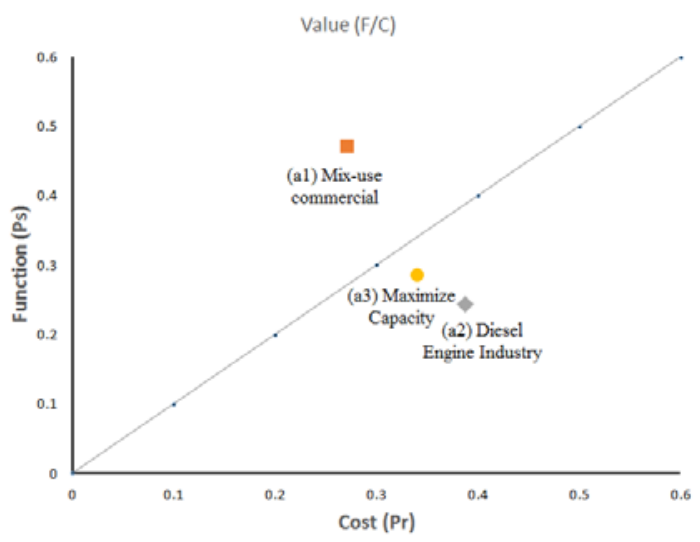

Figure 6. Value of alternative solution

\section{CONCLUSION}

This paper discusses the optimization of SOE land assets with possible development alternatives. HBU analysis are carried out on existing alternatives. MCDM is done to get the best alternative based on stakeholder preferences. Based on the preliminary interview with the stakeholders of the company, an alternative development option that allows to the object research determined: 1 . Developing mixed-use commercial properties; 2. Diesel engine industry; 3. Maximize workshop capacity.

Based on financial analysis shows that development of Mix-use commercial property has the highest Net Present Value with an investment cost of Rp. 1,367,230,380,324. IRR is $20.66 \%$ with a payback period of 6.3 years. Based on AHP analysis with HBU criteria and Value-based decision found that Mixed-use commercial development alternative chosen by stakeholders to optimize SOEs assets.

\section{REFERENCES}

[1] T. Suharto, "Laporan Penilaian Properti Milik PT. BomaBisma Indra (Persero),” Surabaya, 2015.

[2] H. Sucahyo, Y. Rahmawati, and C. Utomo, "A review on maximum productivity of land use in urban project development," in The Third International Conference on Civil Engineering Research (ICCER), 2017.

[3] S. Nugent, "The Asset Journal, Management Council Inc," J. Manag. Asset, vol. 4, 2010.

[4] R. C. Kyle, M. S. Spodek, and F. M. Baird, Property Management, NINTH EDITION. La Crosse, Wisconsin: Kaplan Real Estate Education, 2013.

[5] D. Siregar, Manajemen Aset. Jakarta: Gramedia Pustaka Utama, 2004.

[6] A. Sugiama, Manajemen Aset Pariwisata. Bandung: Guardaya Intimarta, 2013.

[7] Menteri Badan Usaha Milik Negara, PERMEN No. PER13/MBU/09/2014, Tentang Pedoman Pendayagunaan Aset Tetap Badan Usaha Milik Negara. .

[8] Appraisal Institute (U.S.), The Appraisal of Real Estate., 14th edition. Chicago, Illinois: Appraisal Institute, 2013.

[9] B. Harjanto and W. Hidayati, Konsep Dasar Penilaian Properti, 2nd ed. Yogyakarta: BPFE, 2014.

[10] M. Munizzo and L. V. Musial, General Market Analysis and Highest and Best Use. Mason Ohio: Cengage Learning, 2010.

[11] J. J. Kaufman and R. Woodhead, Stimulating Innovation in Products and Services: With Function Analysis and Mapping. Hoboken, New Jersey: Wiley-Interscience, 2006.

[12] Y. Rahmawati and C. Utomo, "Value-based decision for highest and best use," in 2017 International Conference on Engineering Technology and Technopreneurship (ICE2T), 2017, pp. 1-5.

[13] K. Black, Business Statistics : Contemporary Decision Making. Ontario: John Wiley \& Sons, Ltd, 2010.

[14] M. F. Pasaribu and R. Puspita, "Tahap informasi, kreatif, dan analisa pada rekayasa nilai untuk meningkatkan kualitas pelayanan hotel," Ind. Eng. J., vol. 5, no. 2, pp. 46-51, Nov. 2016.

[15] M. E. Miles, L. M. Netherton, and A. Schmitz, Real Estate Development: Principles And Process, Fifth edition. Washington: Urban Land Institute, 2015.

[16] T. L. Saaty, "Decision making - the Analytic Hierarchy and Network Processes (AHP/ANP),” J. Syst. Sci. Syst. Eng., vol. 13, no. 1, pp. 1-35, Mar. 2004.

[17] P. W. Sabrina, "Revitalisasi Kawasan Koridor Kalimas Timur sebagai Objek Wisata," Institut Teknologi Sepuluh Nopember, 2012.

[18] Pemerintah Kota Surabaya, PERDA No. 12/2014, tentang RTRW Kota Surabaya tahun 2014-2034. 2014.

[19] Pemerintah Kota Surabaya, PERDA No. 4/2016, tentang Rencana Rinci Tata Ruang Kota Surabaya. 2016.

[20] W. C. Stirling, Satisficing Games and Decision Making: With Applications to Engineering and Computer Science. Cambridge: Cambridge University Press, 2003. 